\title{
PERLINDUNGAN HUKUM PENGGUNAAN JASA TRANSPORTASI UDARA TERHADAP PENYANDANG DISABILITAS*
}

\author{
Oleh: \\ Ayuning Sasmitha Margana** \\ I Made Udiana ${ }^{* * *}$ \\ A.A. Ketut Sukranatha*** \\ Bagian Hukum Bisnis Fakultas Hukum Universitas Udayana
}

\begin{abstract}
ABSTRAK
Mengingat pentingnya peran transportasi untuk mempermudah pengangkutan manusia maupun barang dari satu tempat asal ke tempat tujuan, maka diperlukan adanya perlindungan hukum penggunaan jasa transportasi. Perlindungan hukum penggunaan jasa transportasi terhadap penyandang disabilitas, khususnya transportasi udara masih kurang efektif dikarenakan masih banyak terdapat tindakan diskriminasi yang dialami oleh penyandang disabilitas, yang dilakukan baik oleh pihak maskapai penerbangan maupun pihak bandar udara. Berdasarkan latar belakang tersebut, rumusan masalah dalam penelitian ini meliputi: 1. Bagaimana perlindungan hukum terhadap penyandang disabilitas sebagai pengguna jasa dalam penggunaan jasa transportasi udara? 2. Upaya hukum apakah yang dapat ditempuh oleh penyandang disabilitas dalam hal terjadinya sengketa dengan pihak maskapai penerbangan?. Penelitian ini menggunakan metode penelitian hukum empiris, dimana lebih menekankan terhadap bentuk perlindungan hukum dan upaya hukum yang dapat ditempuh dalam hal terjadinya sengketa, yang didasarkan pada sumber bahan hukum primer dan bahan hukum sekunder, sedangkan pengumpulan data menggunakan teknik wawancara.

Kesimpulan yang diperoleh dari hasil penelitian ini bahwa masih banyak penyandang disabilitas yang mengalami tindakan diskriminasi pada saat menggunakan jasa transportasi udara, sehingga implementasi dalam perlindungan hukum penggunaan jasa transportasi udara terhadap penyandang disabilitas harus lebih diperhatikan, serta penyandang disabilitas belum semuanya

\footnotetext{
* Makalah ilmiah ini disarikan dan dikembangkan lebih lanjut dari Skripsi yang ditulis oleh penulis atas bimbingan Pembimbing Skripsi I Dr. I Made Udiana, SH., MH dan Pembimbing Skripsi II A.A. Ketut Sukranatha, SH., MH.

** Penulis Pertama : Ayuning Sasmitha Margana adalah mahasiswa Fakultas Hukum Universitas Udayana.

${ }^{* * *}$ Penulis Kedua : Dr. I Made Udiana, SH., MH, adalah Dosen Fakultas Hukum Universitas Udayana.

${ }^{* * * * *}$ Penulis Ketiga : A.A. Ketut Sukranatha, SH., MH, adalah Dosen Fakultas Hukum Universitas Udayana.
} 
mengetahui upaya apa yang dapat ditempuh dalam hal terjadinya sengketa dengan pihak maskapai penerbangan.

\title{
Kata Kunci : Perlindungan Hukum, Transportasi Udara, Penyandang Disabilitas
}

\begin{abstract}
The importance of transportation to make the people or things transport easier, so the legal protection for the user of the transport service is needed. Legal protection of the people with disability transport service user, especially air transportation is still less effective because there is still some discrimination which is done by the airline or the airport. Based on that background, the problem of this study is 1 . How is the legal protection for the people with disability as the user of air transport service? 2. How is the legal effort that can be taken by the people with disability if there is a dispute with the airline?. The method of this study is empirical law study, which emphasizes the form of the legal protection and legal effort which can be taken if there is a dispute, which based on the primary law source and secondary law, and the data are collected by interview technique. The conclusion of this study is that there are so many people with disability that get a discrimination when they use the air transport service, so the implementation of the air transport service legal protection for people with disability must get more attention, and not all people with disability know about the effort that they can do if they have any dispute with the airline.
\end{abstract}

\section{Keywords : Legal Protection, Air Transportation, People with Disability}

\section{PENDAHULUAN}

\subsection{Latar Belakang}

Terdapat tiga macam transportasi antara lain transportasi laut, transportasi udara dan transportasi darat. Pentingnya transportasi bagi masyarakat Indonesia khususnya disebabkan oleh beberapa hal, salah satunya dikarenakan keadaan letak geografis Indonesia yang terdiri atas ribuan pulau besar dan kecil, berupa daratan dan sebagaian besar perairan yang terdiri atas perairan danau, laut dan sungai, ${ }^{1}$ sehingga untuk mempermudah

${ }^{1}$ Abdulkadir Muhammad, 2013, Hukum Pengangkutan Niaga, Cetakan Ke-5, PT Citra Aditya Bakti, Bandung, h.32 
menjangkau seluruh wilayah di Indonesia diperlukan transportasi baik melalui darat, laut, maupun udara.

Secara umum terdapat beberapa subjek dalam pelaksanaan pengangkutan atau transportasi yaitu pengirim atau penumpang dan penyedia jasa pengangkutan atau transportasi, maka masyarakat yang berkedudukan sebagai pengguna jasa dalam hal ini disebut konsumen, perlu mendapatkan prioritas serta pelayanan yang optimal dan perlindungan hukum terhadap hakhaknya selaku konsumen pengguna jasa transportasi baik dari penyedia layanan jasa transportasi maupun dari pemerintah.

Indonesia sebagai negara yang berdasarkan atas hukum, tentunya tidak terlepas dari keterkaitannya dengan hak asasi manusia. ${ }^{2}$ Pada dasarnya, semua hak yang dimiliki oleh manusia berlaku setara bagi penyandang disabilitas. Faktanya masyarakat dengan disabilitas merupakan kelompok minoritas secara jumlah representasi, serta tersubordinasi karena stigma, tingkat pemahaman, serta dominasi politik ditingkat masyarakat dan negara memberikan akses terbatas terhadap penyandang disabilitas. $^{3}$

Mengenai hal perlindungan hukum pemerintah wajib melindungi hak asasi warganya berdasarkan prinsip anti diskriminasi, demokrasi keadilan sosial setara dan persamaan hak. ${ }^{4}$ Diskriminasi adalah suatu tindakan ataupun sikap yang

${ }^{2}$ Desak Made Pratiwi Dharayanti, 2018, "Pemberian Bantuan Hukum Dalam Perkara Pidana Oleh Advokat Dilihat Dari Perspektif Hak Asasi Manusia”, Jurnal Kertha Patrika Vol. 40, No. 3, Desember 2018 Fakultas Hukum Universitas Udayana, URL : https://ojs.unud.ac.id/index.php/kerthapatrika/article/view/44205/27357 diakses tanggal 10 April 2019.

${ }^{3}$ Ni Komang Sutrisni, 2015, "Pengaturan Advokasi Terhadap Hak-Hak Penyandang Disabilitas Terhadap Diskriminasi Dibidang Penegakan Hukum", Jurnal Magister Hukum Vol. 4 No. 1, Mei 2015 Fakultas Hukum Universitas Udayana, URL https://ojs.unud.ac.id/index.php/jmhu/article/view/13044/10821 diakses tanggal 11 April 2019.

${ }^{4}$ I Made Udiana, 2016, Kedudukan dan Kewenagan Pengadilan Hubungan Industrial, Udayana University Press, Bali, h.58 
membeda-bedakan orang lain dalam hal perlakuan, agama, suku bangsa, ras dan lain sebagainya.

Selain transportasi darat dan laut yang sering digunakan dalam pengiriman maupun pengangkutan manusia atau barang, bersamaan dengan pesatnya perkembangan ilmu pengetahuan dan teknologi, permintaan jasa penggunaan transportasi udara pun sudah semakin meluas. Hal ini dikarenakan jasa pelayanan transportasi udara yang memiliki kecepatan tinggi dan dapat memberikan efisiensi dalam hal waktu perjalanan.

Mengingat pentingnya peran transportasi untuk mempermudah pengangkutan manusia maupun barang dari satu tempat asal ke tempat tujuan, maka diperlukan adanya perlindungan hukum penggunaan jasa transportasi. Perlindungan hukum penggunaan jasa transportasi terhadap penyandang disabilitas, khususnya transportasi udara masih kurang efektif dikarenakan masih terdapat tindakan diskriminasi yang dialami oleh penyandang disabilitas, baik dari segi pelayanan, fasilitas maupun aksesibilitas saat menggunakan jasa transportasi udara. Pengadaan aksesibilitas yang memadai tentunya akan membantu penyandang disabilitas dalam melakukan aktivitasnya secara mandiri dan menjauhkan penyandang disabilitas dari tindakan diskriminasi sosial.

Pasal 1 ayat (1) Undang-Undang Nomor 8 Tahun 2016 tentang Penyandang Disabilitas, memberikan definisi yang dimaksud dengan "Penyandang Disabilitas adalah setiap orang yang mengalami keterbatasan fisik, intelektual, mental dan/atau sensorik dalam jangka waktu lama yang dalam berinteraksi dengan lingkungan dapat mengalami hambatan dan kesulitan untuk berpartisipasi secara penuh dan efektif dengan warga negara lainnya berdasarkan kesamaan hak". 


\subsection{Masalah dan Tujuan Penulisan}

Rumusan masalah dalam penelitian ini meliputi:

1. Bagaimana perlindungan hukum terhadap penyandang disabilitas sebagai pengguna jasa dalam penggunaan jasa transportasi udara?

2. Upaya hukum apakah yang dapat ditempuh oleh penyandang disabilitas dalam hal terjadinya sengketa dengan pihak maskapai penerbangan?

Penulisan ini bertujuan untuk mengetahui bagaimana perlindungan hukum penggunaan jasa transportasi udara terhadap penyandang disabilitas.

\section{ISI MAKALAH}

\subsection{Metode Penelitian}

Penulisan karya ilmiah ini menggunakan metode penelitian empiris, dimana lebih menekankan terhadap bentuk perlindungan hukum dan upaya hukum yang dapat ditempuh apabila terjadi sengketa, yang didasarkan pada sumber bahan hukum primer dan bahan hukum sekunder, sedangkan pengumpulan data menggunakan teknik wawancara. Informan dalam penelitian ini adalah PT. Angkasa Pura I, PT. Garuda Indonesia, dan Annika Linden Center.

\subsection{Hasil dan Analisis}

\subsubsection{Implementasi perlindungan hukum penggunaan jasa transportasi udara terhadap penyandang disabilitas}

Perlindungan hukum adalah segala upaya yang dilakukan secara sadar baik oleh lembaga pemerintah dan swasta maupun oleh setiap orang, yang memiliki tujuan untuk keamanan, penguasaan dan pemenuhan kesejahteraan hidup masyarakat agar sama dengan hak-hak asasi yang ada, sebagaimana yang telah diatur dalam Undang-Undang Nomor 39 Tahun 1999 tentang 
Hak Asasi Manusia. Secara teoritis, perlindungan hukum di bagi menjadi 2 jenis, yaitu perlindungan hukum preventif dan perlindungan hukum represif.

1. Perlindungan hukum preventif, kepada rakyat diberikan kesempatan untuk mengajukan keberatan (inspraak) atau pendapatnya sebelum keputusan pemerintah mendapat bentuk yang definitif. Perlindungan hukum preventif bertujuan untuk mencegah terjadinya sengketa.

2. Perlindungan hukum represif, bertujuan untuk menyelesaikan sengketa. Bentuk perlindungan hukum represif berupa sanksi seperti denda, penjara, dan hukuman tambahan yang diberikan apabila sudah terjadi sengketa atau pelanggaran. ${ }^{5}$

Menurut Az. Nasution, hukum perlindungan konsumen adalah bagian dari hukum konsumen yang memuat asas-asas atau kaidah-kaidah yang bersifat mengatur dan mengandung sifat yang melindungi kepentingan konsumen. ${ }^{6}$ Hukum merupakan kumpulan peraturan-peraturan yang mengatur hubungan sosial yang memberikan hak kepada subjek hukum untuk berbuat maupun menuntut sesuatu yang diwajibkan oleh hak itu, dan terlaksananya kewenangan dan/atau hak dan kewajiban tersebut dijamin dengan adanya hukum. ${ }^{7}$

Hubungan hukum ialah suatu hubungan yang terjadi antara dua atau lebih subjek hukum yang berkaitan dengan hak dan kewajiban disatu pihak berhadapan dengan hak dan kewajiban dipihak lain. Hubungan hukum memiliki 3 unsur yaitu:

${ }^{5}$ Philipus M Hadjon, 1987, Perlindungan Hukum Bagi Rakyat di Indonesia (Sebuah Studi tentang Prinsip-Prinsipnya, Penanganannya oleh Pengadilan Dalam Lingkungan Pengadilan Umum dan Pembentukan Peradilan Administrasi Negara), PT Bina Ilmu, Surabaya, h.2

6 Aulia Muthiah, 2018, Hukum Perlindungan Konsumwn Dimensi Hukum Positif dan Ekonomi Syariah, Pustaka Baru Press, Yogyakarta, h.40, dikutip dari Shidarta, Hukum Perlindungan Konsumen, Jakarta: Grasindo, h.11

${ }^{7}$ R. Soeroso, 2011, Pengantar Ilmu Hukum, Sinar Grafika, Jakarta, h.269-270 
1. Adanya orang-orang yang hak dan kewajibannya saling berhadapan.

2. Adanya objek yang berlaku berdasarkan hak dan kewajiban tersebut.

3. Adanya hubungan antara pemilik hak dan pengemban kewajiban atau adanya hubungan atas objek yang bersangkutan. ${ }^{8}$

Hubungan hukum akan timbul apabila memenuhi syarat-syarat: adanya dasar hukum, yaitu peraturan hukum yang mengatur hubungan hukum tersebut dan timbulnya peristiwa hukum. ${ }^{9}$

Menurut penjelasan Bapak Agus Mertha Yasa, Duty Manager Services Internasional dari PT. Garuda Indonesia, hubungan hukum yang terjadi antara penyandang disabilitas selaku pengguna jasa dengan maskapai penerbangan, sama seperti penumpang normal pada umumnya yaitu perjanjian pengangkutan transportasi udara yang berawal dari konsumen melakukan pemesanan atau pembelian tiket baik secara online maupun langsung dan setelah itu akan timbul kewajiban bagi pihak maskapai penerbangan sesuai dengan tiket yang telah dipesan. Adapun yang dimaksud dengan kewajiban yang timbul bagi pihak maskapai penerbangan, maskapai penerbangan wajib memberikan pelayanan tanpa adanya tindakan diskriminasi antara penumpang berkebutuhan khusus dengan penumpang normal pada umumnya serta memberikan fasilitas sesuai dengan standar operasional yang sudah ditentukan tiap-tiap maskapai penerbangan, serta tanpa dikenakan biaya tambahan. Pihak bandara juga memiliki kewajiban untuk menyediakan fasilitas dan aksesibilitas khusus bagi konsumen penyandang disabilitas.

\footnotetext{
${ }^{8}$ Ibid, h.271

${ }^{9}$ Ibid.
} 
Menurut Ibu Handayani Novitasari, Customer Service and Hospitality Officer di PT. Angkasa Pura I (Persero), fasilitas dan aksesibilitas yang diberikan berupa penyediaan wheel chair (kursi roda), memberikan pendamping, memberikan aksesibilitas khusus bagi pengguna kursi roda, menyediakan garbarata (lorong untuk mempermudah penyandang disabilitas khususnya pengguna kursi roda untuk masuk ke dalam pesawat dari ruang tunggu), serta menyediakan toilet khusus bagi pengguna kursi roda.

Menurut penjelasan Ibu Alinda Meisya Nursilawati, Staff Legal Officer di PT. Angkasa Pura I (Persero), menyatakan bahwa peraturan yang mengatur mengenai perlindungan hukum penggunaan jasa transportasi udara diatur dalam Undang-Undang Nomor 1 Tahun 2009 tentang Penerbangan, Undang-Undang Nomor 8 Tahun 1999 tentang Perlindungan Konsumen, Peraturan Menteri Nomor 185 Tahun 2015 tentang Standar Pelayanan Penumpang Kelas Ekonomi Angkutan Udara Niaga Berjadwal Dalam Negeri, serta peraturan perundang-undangan lainnya yang terkait dengan pengangkutan udara.

\subsubsection{Upaya hukum yang dapat ditempuh oleh penyandang disabilitas apabila mengalami sengketa dengan pihak maskapai penerbangan}

Penyelesaian sengketa yang terjadi antara konsumen dengan pelaku usaha, diperlukan kehati-hatian dalam mengenalisis siapa yang harus bertanggung jawab dan menentukan seberapa jauh beban tanggung jawab yang dibebankan kepada pihak-pihak terkait. Pasal 19 sampai Pasal 28 Undang-Undang Perlindungan Konsumen mengatur mengenai tanggung jawab pelaku usaha. Prinsip tanggung jawab dalam hukum secara umum dapat diklasifikasikan menjadi lima yakni: 
1. Prinsip tanggung jawab karena kesalahan (liability based on fault);

2. Prinsip praduga selalu bertanggung jawab (presumption of liability);

3. Prinsip praduga selalu tidak bertanggung jawab (presumption of nonliability);

4. Prinsip tanggung jawab mutlak (strict liability);

5. Prinsip pembatasan tanggung jawab (limitation of liability). ${ }^{10}$

Perilaku perusahaan acapkali terlihat mengabaikan aspek sosial yang sesungguhnya sangat mendukung keberlangsungan usaha perusahaan. Pengabaian aspek sosial tidak jarang berujung konflik antara perusahaan dengan masyarakat disekitarnya. ${ }^{11}$ Kendala-kendala yang pernah dialami penyandang disabilitas sebagai pengguna jasa transportasi udara, berdasarkan penjelasan Sang Ayu Nyoman Puspa, sebagai salah satu penyandang disabilitas pengguna kursi roda, menyatakan pada saat ia melakukan check in di loket, ia pernah diminta untuk membayar biaya tambahan terkait dengan fasilitas dan pelayanan khusus yang diberikan oleh pihak maskapai penerbangan, selain itu ia pernah dipaksa untuk menandatangani surat sakit agar tetap dapat melanjutkan penerbangannya tanpa diberikan penjelasan yang jelas mengenai surat sakit tersebut. Meskipun pada dasarnya penyandang disabilitas tidak termasuk ke dalam kelompok orang sakit.

Menurut penjelasan Dewa Ayu Putri, sebagai salah satu penyandang disabilitas tuli (tidak dapat mendengar), menyatakan

\footnotetext{
${ }^{10}$ Celina Tri Siwi Kristiyanti, 2018, Hukum Perlindungan Konsumen, Cetakan Ke-7, Sinar Grafika, Jakarta, h. 92.

${ }^{11}$ Ida Ayu Sukihana dan I Gede Agus Kurniawan, 2017, "Tanggung Jawab Perusahaan Dari Profit Menuju Stakeholders Oriented Studi Csr Di Tabanan”, Jurnal Kertha Patrika, Vol. 39, No. 3, Desember 2017 Fakultas Hukum Universitas Udayana, URL : https://ojs.unud.ac.id/index.php/kerthapatrika/article/view/39984/24380 diakses tanggal 10 April 2019.
} 
bahwa kendala yang ia alami pada saat menggunakan jasa transportasi udara yaitu kesulitan dalam melakukan interaksi atau komunikasi dengan pihak bandar udara yang bertugas saat sedang ingin melakukan check in di loket, karena tidak ada staff maupun pendamping dari pihak bandar udara maupun maskapai penerbangan yang bisa menggunakan bahasa isyarat. Menurut penjelasan Gede Agus Arnawa, sebagai salah satu penyandang disabilitas pengguna kaki palsu, menyatakan bahwa pada saat ia sampai di bandara tentunya ia tetap harus melakukan proses security check di pintu keberangkatan menuju loket check in sama seperti penumpang pada umumnya, hanya saja sebagai pengguna kaki palsu ketika ia melewati gerbang sensor ia merasa menarik perhatian publik, karena sensor tersebut berbunyi yang disebabkan oleh kaki palsunya. Jadi secara tidak langsung ia merasa malu karena menjadi sorotan publik.

Tanggung jawab yang diberikan, menurut penjelasan Ibu Handayani Novitasari, Customer Service and Hospitality Officer di PT. Angkasa Pura I (Persero), menyatakan penyandang disabilitas yang menggunakan jasa transportasi udara pada saat sampai di drop zone area sebelum masuk ke loket check in akan diterima oleh salah satu staff yang bertugas dan mencatat penumpang yang berkebutuhan khusus tersebut, kemudian mengisi formulir penumpang berkebutuhan khusus dan formulir tersebut yang akan digunakan untuk serah terima penumpang yang berkebutuhan khusus dengan pihak maskapai penerbangan. Formulir tersebut juga berguna jika ada penumpang yang komplain terhadap pelayanan pihak bandar udara, dari formulir tersebut dapat diketahui siapa yang bertugas pada saat itu. Pihak bandar udara memiliki asuransi bagi para penumpang yang normal pada umumnya maupun penumpang penyandang 
disabilitas, asuransi yang diberikan oleh pihak bandar udara terhadap penumpang penyandang disabilitas sama seperti penumpang pada umumnya.

Menurut penjelasan Bapak Agus Mertha Yasa, Duty Manager Services Internasional dari PT Garuda Indonesia, bahwa tanggung jawab maskapai penerbangan di PT Garuda Indonesia khususnya terhadap penumpang berupa pemberian biaya ganti rugi apabila maskapai Garuda Indonesia melakukan kesalahan, pihak maskapai penerbangan akan melakukan klarifikasi terlebih dahulu dan memastikan kesalahan apa yang dilakukan. Biaya ganti rugi yang ditawarkan berupa menaikan class atau mengupgrade pelayanan dari ekonomi menjadi pelayanan kelas bisnis, apabila pesawat penumpang yang bersangkutan dibatalkan penerbangannya dan diganti dengan penerbangan hari berikutnya, pihak maskapai penerbangan akan memberikan fasilitas untuk menginap di hotel, selain itu bentuk tanggung jawab lainnya berupa memberikan biaya ganti rugi sebesar 40\% (empat puluh persen) dari harga tiket penumpang yang bersangkutan. Selain biaya ganti rugi pihak maskapai penerbangan juga memiliki asuransi untuk penumpang sebagai bentuk tanggung jawab maskapai penerbangan.

Penyelesaian sengketa konsumen dapat dilakukan dengan beberapa cara yaitu melalui jalur litigasi dan non litigasi. Penyelesaian sengketa dengan jalur litigasi yaitu menyelesaikan sengketa melalui pengadilan, pengadilan bertugas untuk menyelesaikan sengketa yang timbul dan memberikan putusan yang adil antara pelaku usaha maupun konsumen. ${ }^{12}$ Penyelesaian sengketa dengan jalur non litigasi yaitu melalui forum musyawarah antara pelaku usaha dengan konsumen sesuai

\footnotetext{
${ }^{12}$ Aulia Muthiah, op.cit, h.218
} 
dengan Pasal 45 ayat (2) UUPK. Penyelesaian sengketa melalui BPSK dapat diawali dengan prasidang, yang tujuannya untuk menggali informasi sejauh mana kekuatan masing-masing pihak. Pada tahap prasidang pihak BPSK akan mengarahkan pelaku usaha dan konsumen yang bersengketa untuk memilih metode yang akan digunakan untuk menyelesaikan sengketa antara kedua belah pihak. Penyelesaian sengketa melalui BPSK dilakukan tidak berjenjang, yang artinya jika konsumen dan pelaku usaha telah memilih salah satu metode penyelesaian sengketa di BPSK, maka tidak boleh memilih metode lainnya untuk menyelesaikan sengketa antara pelaku usaha dengan konsumen. Pasal 52 huruf a UUPK merumuskan bahwa BPSK akan menyelesaikan sengketa konsumen dengan jalan melalui mediasi, konsiliasi, dan arbitrase. ${ }^{13}$

Menurut penjelasan Ibu Alinda Meisya Nursilawati, Staff Legal Officer di PT. Angkasa Pura I (Persero), menyatakan bahwa jika terjadi sengketa antara penumpang dengan bandar udara maupun maskapai penerbangan dan menempuh jalur litigasi (pengadilan) sampai saat ini sanksi yang diberikan masih berupa sanksi administratif, yaitu sanksi yang berupa denda, pencabutan maupun pembekuan sertifikat dan/atau izin usaha, penghentian sementara pelayanan administrasi, dan lain sebagainya. Selain sanksi administratif belum terdapat peraturan yang konkret mengenai batas tanggung jawab yang harus diberikan.

\section{PENUTUP}

\subsection{Kesimpulan}

1. Perlindungan hukum penggunaan jasa transportasi udara terhadap penyandang disabilitas, berupa pengawasan dan tanggung jawab dari PT. Angkasa Pura I sebagai pihak

\footnotetext{
${ }^{13}$ Aulia Muthiah, op.cit, h.212-215
} 
pengelola bandara dan PT. Garuda Indonesia sebagai pihak maskapai penerbangan. Berdasarkan pada prinsip perlindungan hukum preventif dan perlindungan hukum represif, serta peraturan perundang-undangan yang terkait : Undang-Undang Nomor 8 Tahun 1999 tentang Perlindungan Konsumen, Undang-Undang Nomor 1 Tahun 2009 tentang Penerbangan, Undang-Undang Nomor 8 Tahun 2016 tentang Penyandang Disabilitas, dan Undang-Undang Nomor 39 Tahun 1999 tentang Hak Asasi Manusia.

2. Upaya hukum yang dapat ditempuh oleh penyandang disabilitas dalam hal terjadinya sengketa dengan pihak maskapai penerbangan yaitu dapat melalui beberapa jalur yakni jalur litigasi dan non-litigasi. Dalam kasus ini jalur yang ditempuh adalah jalur litigasi atau pengadilan sampai saat ini sanksi yang diberikan berupa sanksi administratif jika terbukti pihak maskapai penerbangan maupun pihak pengelola bandar udara melakukan kelalaian.

\subsection{Saran-saran}

1. Pihak pengelola bandara PT. Angkasa Pura I sebaiknya menyediakan alat khusus maupun cara khusus untuk penyandang disabilitas yang menggunakan kaki palsu khususnya pada saat melakukan proses security check, pihak bandara juga sebaiknya menyediakan staff khusus yang dapat mengerti bahasa isyarat untuk berkomunikasi dengan penyandang disabilitas yang tuli. Sedangkan pihak maskapai penerbangan PT. Garuda Indonesia sebaiknya mencantumkan ketentuan yang jelas mengenai penandatanganan formulir informasi medis dan surat pernyataan pembebasan tanggung jawab, agar penumpang penyandang disabilitas yang kurang 
mengerti akan akibatnya menjadi lebih memahami dan tidak ada staff yang menyalah gunakan formulir tersebut.

2. Pihak lembaga pemerintahan yang terkait dengan penyedia pelayanan jasa transportasi udara, sebaiknya memberikan bentuk pertanggungjawaban dan jumlah besaran ganti kerugian yang diatur dalam peraturan perundang-undangan, agar memperjelas hak dan kewajiban atas pertanggungjawaban ganti kerugian dari pihak maskapai penerbangan maupun bandara kepada pengguna jasa baik penumpang normal pada umumnya maupun pada penumpang penyandang disabilitas.

\section{DAFTAR PUSTAKA}

\section{Buku}

Abdulkadir Muhammad, 2013, Hukum Pengangkutan Niaga, Cetakan ke-5, PT Citra Aditya Bakti, Bandung.

Aulia Muthiah, 2018, Hukum Perlindungan Konsumen Dimensi Hukum Positif dan Hukum Ekonomi Syariah, Pustaka Baru Press, Yogyakarta.

Celina Tri Siwi Kristiyanti, 2018, Hukum Perlindungan Konsumen, Cetakan ke-7, Sinar Grafika, Jakarta.

Philipus M Hadjon, 1987, Perlindungan Hukum Bagi Rakyat di Indonesia (Sebuah Studi tentang Prinsip-Prinsipnya, Penanganannya oleh Pengadilan Dalam Lingkungan Pengadilan Umum dan Pembentukan Peradilan Administrasi Negara), PT Bina Ilmu, Surabaya.

R. Soeroso, 2011, Pengantar Ilmu Hukum, Sinar Grafika, Jakarta.

Udiana, I Made, 2016, Kedudukan dan Kewenangan Pengadilan Hubungan Industrial, Cetakan Kedua, Udayana University Press, Bali.

\section{Jurnal Ilmiah}

Ni Komang Sutrisni, 2015, "Pengaturan Advokasi Terhadap HakHak Penyandang Disabilitas Terhadap Diskriminasi Dibidang Penegakan Hukum", Jurnal Magister Hukum Vol. 4 No. 1, Mei 2015 Fakultas Hukum Universitas Udayana, URL : 
https://ojs.unud.ac.id/index.php/jmhu/article/view/13044/ $\underline{10821}$

Ida Ayu Sukihana dan I Gede Agus Kurniawan, 2017, “Tanggung Jawab Perusahaan Dari Profit Menuju Stakeholders Oriented Studi Csr Di Tabanan", Jurnal Kertha Patrika, Vol. 39, No. 3, Desember 2017 Fakultas Hukum Universitas Udayana, URL : https://ojs.unud.ac.id/index.php/kerthapatrika/article/view $39984 / 24380$

Desak Made Pratiwi Dharayanti, 2018, "Pemberian Bantuan Hukum Dalam Perkara Pidana Oleh Advokat Dilihat Dari Perspektif Hak Asasi Manusia", Jurnal Kertha Patrika Vol. 40, No. 3, Desember 2018 Fakultas Hukum Universitas Udayana, URL https://ojs.unud.ac.id/index.php/kerthapatrika/article/view $\not 44205 / 27357$

\section{Perundang-Undangan}

Undang-Undang Nomor 8 Tahun 1999 tentang Perlindungan Konsumen, Lembaran Negara Republik Indonesia Tahun 1999 Nomor 42, Tambahan Lembaran Negara Republik Indonesia Nomor 3821.

Undang-Undang Nomor 39 Tahun 1999 tentang Hak Asasi Manusia, Lembaran Negara Republik Indonesia Tahun 1999 Nomor 165, Tambahan Lembaran Negara Republik Indonesia Nomor 3886.

Undang-Undang Nomor 1 Tahun 2009 tentang Penerbangan, Lembaran Negara Republik Indonesia Tahun 2009 Nomor 1, Tambahan Lembaran Negara Republik Indonesia Nomor 4956.

Undang-Undang Nomor 8 Tahun 2016 tentang Penyandang Disabilitas, Lembaran Negara Republik Indonesia Tahun 2016 Nomor 69, Tambahan Lembaran Negara Republik Indonesia Nomor 5871. 